\title{
Are Bureaucrats Really Paid Like Bureaucrats?*
}

\author{
Ruben Enikolopov ${ }^{\dagger}$ \\ New Economic School
}

\begin{abstract}
Traditionally, bureaucrats are viewed as a stereotypical example of employees with flat pay schedules and low-powered incentive schemes. This paper challenges this view by providing evidence that wages of a particular group of senior bureaucrats - city managers - are tightly connected to their performance. In particular, salaries of city managers are strongly linked to city growth. Additional tests indicate that these results reflect reward for performance, rather than rent extraction, as exogenous shocks to city growth do not affect city managers' wage. This evidence demonstrates that at least for some bureaucrats there is a strong association between performance and compensation. Competition among local governments is likely to be the main force that sustains highpowered incentives for city managers.
\end{abstract}

\section{Introduction}

When economists want to emphasis that employees face low-powered incentives and their monetary compensation does not respond to performance they often say that these employees are "paid like bureaucrats". The comparison is so popular that it made into the

\footnotetext{
${ }^{*}$ I would like to thank Taubman Center for State and Local Government for generous financial support.

${ }^{\dagger}$ New Economic School, Office 922, Nakhimovsky pr. 47 Moscow 117418 Russia. E-mail: REnikolopov@nes.ru
} 
title of two well known papers that study compensation of such different groups as CEOs of the large U.S. companies and state governors. ${ }^{1}$ However, there is still no empirical evidence on the compensation of high level appointed public officials to support this view. All the evidence so far is limited to rank and file public employees who can not be compared with to politicians or high rank managers in corporations. A more adequate comparison is with bureaucrats who also occupy a senior position within hierarchy. I this paper I look at city managers as an example of such senior bureaucrats. To the best of my knowledge this paper provides the first empirical analysis of the connection between bureaucratic pay for high ranked public officials and their performance. The results contradict the common assumption that all the bureaucrats face low-powered incentives.

To study how monitary remuneration of bureaucrats depends on their performance I use data on salaries of city managers in the U.S. municipalities. City manager serves as a chief executive of municipalities with council-manager form of government. They are appointed by city council and have full responsibility over the day-to-day operation of local government. Thus, city managers can be considered as an example of senior bureaucrats who are appointed by elected public officials and have considerable authority and independence in running the organization they are heading.

I construct a city manager-community matched panel data set to track career path of city managers across different communities over time. I collect information on salaries and individual characteristics of city managers, as well as basic socioeconomic characteristics of the cities. The data set covers 1224 municipalities and 651 city manager over the period between 1992 and 2003.

Using this data set I analyze how performance of city managers affects their wage. I use size of population and tax revenues as measures of performance. To separate increase in

\footnotetext{
1 "Are CEOs Really Paid Like Bureaucrats?" by Brian Hall and Jeffrey Liebman (1998) and "Are Politicians Really Paid Like Bureaucrats?" by Rafael DiTella and Raymond Fisman (2004).
} 
tax revenues that comes from expanding tax base and from increase in tax rate, I consider separately total change in tax revenues and change in tax revenues that comes as a result of population growth. Empirical results indicate that both population growth and growth of tax revenues lead to higher wages of city managers.

There are four alternative theories that can explain positive relationship between city growth and wage of city manager. ${ }^{2}$ First, wage can be increased as a reward for good performance to induce higher level of effort in promoting good policies and make the pay consistent with revealed abilities of city manager. Second, increase in wages can reflect higher rent extraction by public officials. As long as size of rents is proportional to size of city, this will induce positive correlation between city growth and wages of city managers. Third, the wage of city manager can be increased to keep constant his relative position in city's distribution of income. As long as city growth reflects increasing income of city population this will induce correlation between city growth and wage of city managers. Finally, it might be harder to run bigger cities, so the wage of city managers can be increased to compensate for higher workload.

I provide several additional tests to distinguish between these alternative explanations. First, I show that salary of city managers does not react to observable exogenous shocks to measures of city performance. Next, I show that performance affects city managers' wage not only in the city in which they are currently employed, but also in the city in which they work afterwards. I also show that wages of mayors, who do not play important role in running the cities with council-manager form of government, are not sensitive to city performance. Finally, I show that performance elasticity of pay is not affected by the strength of democratic institutions, measured by the availability of voter initiative.

Overall, the results indicate that strong correlation between wages of city managers and

\footnotetext{
${ }^{2}$ The first three of them are similar to the ones described in DiTella and Fisman (2004) for performance elasticity of pay of governors.
} 
city growth is consistent with the reward for performance explanation, but is hard to reconcile with rent extraction, constant relative income, or workload compensation explanations. Thus, emprical results indicate that city managers have strong monetary incentives that encourage them to foster city growth.

The paper demonstrates that some bureaucrats face high powered incentives. Clearly, this does not indicate that bureaucrats in general face strong monetary incentives. City managers are senior bureaucrats who have considerable authority and independence in their work and are likely to face very different incentives than rank and file bureaucrats. Even in comparison with other senior bureaucrats city managers are likely to have stronger incentives, because of competition between local governments.

The literature mentions two major reasons why bureaucrats are facing low powered incentives (Tirole, 1994). The first problem is that it is hard to measure precisely the performance of public officials. One of the reasons for that is the monopoly position that government agencies usually have, which makes it hard to provide relevant comparison for the work of bureaucrats. The second challenge is the multiplicity of goals that public officials have, not all of which are easily measured. Both of these problems are significantly alleviated in the case of local governments. As was noted in a seminal paper by Tiebout (1956), competition between local governments may help to overcome many problems inherent in the public sector. In particular, it helps to provide a relevant comparison for assessing the performance of public officials. In addition, intense competition between local governments can help city managers to monetize their reputation, since local governments have to increase wages of able city managers to prevent them from moving to a different city. Finally, high mobility of population provides a good measure for the performance of public officials. In the case of local governments citizens can signal their satisfaction with a local government by voting with their feet. Thus, changes in city population can serve as 
a metric for assessing the work of city managers.

Theoretical literature on the incentives of the bureaucrats considers several important motivating factors including willingness to stay in office (as in Maskin and Tirole, 2004), career concerns (Wilson, 1989; Alesina and Tabellini, 2007, 2008), or desire to guarantee autonomy and independence (Carpenter, 2001), but almost never mentions monetary reward for performance as an important factor. There is no empirical literature that studies the determinants of monetary income of bureaucrats or bureaucratic incentives more generally, although there is a considerable body of closely related research that studies determinants of payoffs of elected public officials. DiTella and Fisman (2004) provide evidence that gubernatorial wages in the U.S. respond to changes in state income per capita and taxes. Besley and Case (1996) show that state economic performance has important effect on the reelection probabilities of U.S. governors and that voters take into account information from the neighboring states to filter signal from the noise, although Wolfers (2007) shows that voters still react to noise. In addition, there is a growing literature that provides empirical study of the consequences of different incentives of elected politicians and bureaucrats (e.g. Besley and Coate, 2003; Enikolopov, 2010; Coate and Knight, 2010 ).

The remainder of the paper is organized as follows: The next section provides basic information on council-manager form of government. Section 3 provides description of the data. Section 4 provides results of the analyzes of performance elasticity of city managers' compensation. Conclusions follow in section 5 .

\section{Background information}

City manager is a chief executive in local governments with council-manager form of government. Council-manager form of government is one of the two main forms of municipal government in the U.S. (along with mayor-council form of government). In cities with this 
type of government, an elected city council appoints a city manager as a chief executive. City manager has full responsibility of the day-to-day operation of the local government and has authority to oversee department heads, hire and fire local governments' staff (often including department heads), recommend policy to the council and prepare the budget. The wage of the city manager is determined by the city council, which is also responsible for setting policy, adopting legislation and budget.

Council-manager form of government is used in the majority of U.S. cities with population above 12,000. In smaller cities this form of government is much less popular. It is usually used in wealthier communities, since it is a more expensive form of government. City managers are professionals, who have either a special education or sufficient experience of working in a local government. For most of the city managers this is a life-long career approximately $80 \%$ of city managers have as their next occupation position of a city manager in a different city (Enikolopov, 2010). Market for city managers is very mobile with city managers usually coming from a different city and often from a different state. In the sample of city managers used in the paper for more than $40 \%$ of city managers their next position is city manager in a different state.

\section{Data}

\subsection{Sample Construction}

I start with the data from the Salaries of Municipal Officials survey for the years 1992-2003 (excluding 1994). This is an annual survey conducted by the International City/County Management Association (ICMA) that reports the form of municipal government, the name and the salary of main city officials, which for municipalities with council-manager form

of government includes city manager. From this data set I identify the names of the city 
mangers that appear in more than one city. Using Who's Who in Local Government Management database provided by ICMA I check whether these names correspond to the same person and collect information on personal characteristics and the exact dates that this person worked as a city manager in each of the municipalities.

For each municipality that has at least one observation in the sample outlined above I collect information on tax revenues and population statistics for the years 1990-2003. Budget information comes from Finance Statistics part of the Censuses and Annual Surveys of Governments by the U.S. Bureau of Census. Information on the population of the municipalities was collected from the annual population estimates provided by the U.S. Bureau of Census. The definition, sources and construction of variables is described in greater detail in Appendix. For the analysis of the effect of voters initiative on the performance elasticity of pay, I collect information on the existence of voter initiative at the city level from Municipal Form of Government survey conducted by ICMA in 1997 and 2002.

\subsection{Sample description}

In the analysis I focus on the city managers that were observed in more than one city. There are two main reasons for limiting the analysis to this subsample rather than using all the available information from the salary survey. First, the information on the form of government was rechecked manually during the collection of data on city managers, which eliminates possible concerns with miscoding. ${ }^{3}$ Second, for this subsample I have the information on the exact dates at which a given city manager worked in a given community, which allows me to control for city manager-city fixed effects.

The data set contains information on 651 city managers that were observed in more than

\footnotetext{
${ }^{3}$ If municipality with mayor-council form of government is miscoded as having council-manager form of government, the salary of chief administrative officer will be coded as the salary of city manager. The role of CAOs in cities with mayor-council form of government is very different from city managers, which is likely to be reflected in their wage structure. Thus, adding them to the sample can bias the results.
} 
one municipality. Of these city managers 560 are observed in two different municipalities, 76 in three, 13 in four, and 2 in five different municipalities. Table 1 presents summary statistics for personal characteristics of these city managers. Almost $85 \%$ of them have a graduate degree, with almost $60 \%$ having a graduate degree in public administration or closely related field. Only $4.6 \%$ of city managers in the sample are women. Percentage of black or Hispanic city managers is 1.7 and 1.9 respectively. The average length of stay in office in the sample is 5.5 years if we count city managers that are currently in office and 5.0 if we exclude them. The average age of a city manager at the time of start of work is 43 years.

Table 2 presents summary statistics for the main socioeconomic characteristics of municipalities. The first three columns report summary statistics for the final sample that includes only those municipalities in which at least one city manager was observed working in another municipality. By construction, this sample includes only municipalities with council-manager form of government. Compared to the subsample of municipalities covered by the salary survey (columns (4)-(6)), these municipalities have slightly higher population and smaller size of tax revenues and public employment, but in all other respects they appear to be very similar. Thus, there is no evidence that this sample is systematically biased in coverage compared to the salary information sample.

The salary survey is sent to all municipalities with population above 2500 and those under 2500 that have council-manager form of government. As a result, the sample is biased towards larger municipalities and municipalities with council-manager form of government. Comparison of the summary statistics confirms this bias. Municipalities covered by the salary survey are larger, more urbanized, have higher income per capita and higher size of tax revenues than average municipality in Censuses of Governments (columns (7)-(9)). 


\subsection{Wages of City Managers}

Panel A of Table 3 presents how real wages of city managers (measured in 2000 dollars) were changing between 1002 and 2003. During this period city managers experienced a noticeable increase in real wages. The real median wage of city managers from 1992 to 2003 increased by 20 percent, which was roughly in line with an increase in the average wage of full-time local public employees (see Figure 1). The variance of city managers' wages across municipalities during this period remains constant during the whole period. The ratio of standard deviation to mean is approximately $36 \%$ for all the years in the sample. Wages of city managers that were observed in at least two municipalities are only slightly higher than wages of city managers in the full sample and are growing with the same rate. ${ }^{4}$ The difference disappears completely in the second half of the period under consideration.

Panel B of Table 3 presents information on the changes in nominal wages of city managers that are observed in more than one city. One of the important features of the data is that nominal wages of city managers exhibits noticeable variation over time. The nomianl wage of a city manager who stays in the same city remains constant in only $10 \%$ of the cases and almost never stays the same if a manager moves to another city. Although in most of the cases the wages of city managers are growing both if they stay in the same city or if they move to a different city, there is a noticieable number of cases in whichcity managers experience a decrease in their nomianl wage. This happens in almost 10 percent of case if they stay in the same city and in more than 20 percen of cases if they move to a different city.

\footnotetext{
${ }^{4}$ The fact that wages of these city managers are somewhat higher can be driven by the fact that more successful city managers have higher wage and are more likely to be found working as city managers in other municipalities.
} 


\subsection{Measures of City Growth}

As measures of performance I use city population and tax revenues. Unfortunately, more direct measures of city's economic development, such as income per capita, are measured only during dicennial censuses and, thus, are not suitable for the analysis in the paper. The use of the first measure is justified by high population mobility among different cities in the U.S. People are moving to the places that offer them better standards of living, so that changes in the size of population can be used as an indicator of city development. The exact measure that I use is the estimate of the size of population in municipality computed by Census Bureau. It uses data from decennial census as a base and calculates yearly changes in population using variety of inputs including the number of building permits issued, administrative records, mobile home shipments etc. The main drawback of this measure is that it relies on estimation, rather than direct measure of city population. This makes it a very noisy measure of actual city development, so that the results are likely to be biased downwards as a result of the measurement error. Another drawback of this measure is that changes in population are likely to respond to changes in city conditions

only slowly, so that annual variation might not adequately reflect the results of the work of city managers.

The second measure of city growth is the size of tax revenues. An advantage of this measure is that it relies on real data, rather than estimates. The main drawback of this measure is that it can not be unambiguously interpreted as evidence of city growth for which city managers should be rewarded. An increase in tax revenues can occur either as a result of an increase in the tax base, or as a result of an increase in the tax rate. While an increase in the tax base can be interpreted as resulting from the growth of the city that should be rewarded, an increase in the tax rate is usually treated as an undesirable policy for which elected public officials are punished by the voters (Peltzman, 1992; Di Tella and 
Fisman, 2004). Unfortunately, the data on changes in tax rates in the municipalities in the sample is not available, so I can not directly separate these two effects. To get around this problem I instrument the size of tax revenues with the estimates of population. This allows me to look at only the component of tax revenues that occurs due to an increase in the number of tax payers.

\section{Empirical Results}

In the empirical part I start with the analysis of the relationship between measures of city growth and city manager's salary. Then I perform several test to distinguish between reward for performance, rent seeking, constant relative income, and compensating differential explanations of this relationship.

\subsection{Salary in the same city}

To see whether city managers are compensated with higher wage for city growth, I estimate the following regression:

$$
\ln \left(\text { Wage }_{i j t}\right)=\alpha \times \text { Performance }_{i j t}+\text { Controls }_{i j}+\delta_{t}+\epsilon_{i j t}
$$

where $\ln \left(W_{a g} e_{i j t}\right)$ is the $\log$ of city manager $i$ wage in city $j$ and year $t$, Performance $_{i j t}$ is a measure of performance such as the log of population or log of tax revenues, ${ }^{5} \delta$ is a year fixed effect, and Controls $s_{i j}$ is a set of controls that in different specifications includes municipality fixed effect, individual characteristics of city managers and city manager-municipality fixed effects.

Results of the estimation are reported in Table 4. First, I estimate specification with

\footnotetext{
${ }^{5}$ To smooth the measures of performance I take the avareage of the corresponding measures over the last two years.
} 
municipal fixed effects with several individual-level control variables that include city manager's age and age squared, the log of tenure in office, dummy variables for sex, black and Hispanic. Next, I estimate specification that control for city manager-municipality fixed effect instead of municipality fixed effect. There is a strong evidence that the wage of the city managers is not flat and responds to the measures of performance. Both increase in population and increase in tax revenues lead to an increase in city manager's wage. A 10 percent increase in city's population leads an increase in the wage of city manager of between 1.6 and 1.9 percent. A 10 percent increase in tax revenue leads to a 0.4 percent increase in the wage of city manager. The effect of a change in tax revenues due to changing size of population, turns out to be significant in both specifications and the magnitude of the effect increases. Controlling for municipality fixed-effects a 10 percent increase in tax revenue caused by an increase in population leads to a 1.9 percent increase in the wage of city manager. Controlling for city manager-municiaplity fixed effects this coefficient goes up, so that a 10 percent increase in tax revenue caused by an increase in population leads to a 2.9 percent increase in the wage of city manager. Between the two measures, population apperas to be a more important determinant of city manager's wage, as the effect of tax revenue becomes insignificant if both measures of city growth are included in the same regression. These results, however, must be treated with extreme caution, as both measures are highly correlated.

To make sure that the results are not sample-specific, I estimate the same regressions using the sample of all city managers for whom the salary information is available. The magnitude and statistical significance of the results (see Table 5) are very similar to the ones reported in Table 4. Thus, there is no evidence that restricting the sample affects the results.

It is hard to compare directly quantitative estimates of elasticities above with the sim- 
ilar estimates for performance elasticity of pay for state governors and CEOs, since they are based on different measures of performance. Di Tella an Fisman (2004) show that a 10 percent increase in income per capita in a state is associated with a 4.5 percent increase in the governor's wage, which is almost twice larger than the estimates of the CEO compensation with respect to firm returns (Murphy, 1999; Hall and Liebman, 1998). Since annual information on income per capita for municipalities run by city managers is not available, I can not estimate directly the elasticity of city manager's wage with respect to income per capita. However, I can assess this elasticity by combining the estimates form Tables 4 and 5 with estimates for the elasticities of population with respect to income per capita estimated for the same cities using the data from decennial census. The elasticity of population with respect to income per capita in the sample of municipalities under consideration (controlling for municipality and year fixed effects) is approximately 0.33 . Thus, the implied elasticity of city manager's wage with respect to income per capita is approximately 0.06 , which is notably smaller than the similar estimate for the governors and is closer to the estimates for the CEOs for the beginning of 80's. At the same time, the results for city managers are more likely to suffer from attenuation bias due to measurement error, which would lead to a downward bias in the estimates of elasticities.

\subsection{Effect of Observable Shocks}

According to the reward for performance explanation wages of city managers should not respond to changes in measures of city performance that come as a result of observable shocks beyond city managers' control. To identify exogenous shocks to local economy I construct a "Bartik instrument" following the approach developed by Bartik (1991) and employed by Blanchard and Katz (1991), Bound and Holzer (2000), Autor and Dugger (2003). To construct the instrument I interact community-level industry composition of 
employment with national-level changes in employment across industries. The intuition behind the instrument is that a nationwide shock to a particular industry will have especially strong effect on the communities in which the share of people employed in this industry is high. Industry-specific nationwide shocks are plausibly exogenous to conditions in either local community as long as an industry is not concentrated in a particular community. At high level of industry aggregation this condition is very likely to hold, so that this instrument satisfies the exclusion restriction.

The instrument was constructed using the following formula:

$$
\varepsilon_{i t}=\sum_{j}\left(\frac{e_{i j, 1990}}{e_{i, 1990}}\right)\left(\frac{e_{j t}-e_{j t-1}}{e_{j t-1}}\right)
$$

where $e_{i j, 1990}$ is employment in community $i$ in industry $j$ in the year 1990 and $e_{i t}$ is a national industry employment in year $t$. Information on the community-level employment comes from Census of Population and Housing 1990. Information on national employment comes from BLS statistics. Since shocks can have a lasting effect, I take six-year average of the shocks calculated using (2). ${ }^{6}$

The instrument turns out to be a good predictor of the population of a city, but a poor predictor of tax revenues of a local government. The results of the first-stage regression (see Table 7) indicate that the coefficient for the Bartik instrument in the first two columns is highly significant, so that the results are not affected by the weak instrument problem. In the last two columns, however, the predictive power of the instrument is so small, that the results of the IV estimation can not be meaningfully interpreted.

I estimate the same regressions as in (1) with all the measures of performance instrumented by Bartik instrument. Table 6 presents the results of the estimations. The results show that there is no evidence that the wage of city managers responds to observable

\footnotetext{
${ }^{6}$ The number of years was chosen to maximize the predictive power in the first-stage regression.
} 
shocks. Compared to the results of uninstrumented regressions (see Table 4) elasticity of pay with respect to population changes its sign in the regression with city fixed effects and is insignificant in the regression with city manager-city fixed effects. Similar pattern holds for tax reveneues, although these results can not be meaningfully interpreted because of poor predictve power of the instrument.

Overall, the evidence suggests that salary of city managers does not respond to observable shock, which is consistent with the reward for performance model, but can not be explained by the other three theories.

\subsection{Salary in the next city}

Next, I look at the effect of city growth on the wage of city manager in the next city in which the manager works. If measures of city growth reflect city manager's ability to run local government and this ability is not specific to a particular city, such measures should affect not only the current wage, but also the wage in the next city in which city manager works. In contrast, if the association between measures of city growth and wages is driven by rent-extraction, constant relative income considerations, or compensation for a more challenging job, there is no immediate reason for these measures to affect city managers' wage in the next city, controlling for the size of the next city.

To assess how performance of city manager affects his/her wage in the next city I estimate the following regression

$$
\ln \left(\text { Wage_next } t_{i j t}\right)=\alpha \times \text { Performance } \text { fijt }_{t}+\beta \times \text { Controls }_{i j t}+\delta_{t}+\epsilon_{i j t}
$$

where $\ln \left(\right.$ Wage_next $\left.t_{i j t}\right)$ is the log of the starting wage in the next city for city manager $i$ that was working for the last year in city $j$ at year $t$, Performance $_{i j t}$ are the same measure of performance as in regression (1) measured at the last year before city manager 
moved to another city, $\delta$ is a year fixed effect, and Controls $s_{i j t}$ is a set of controls that includes city manager's age and age squared, and initial level of the corresponding measure of performance in city $j$. Since tenure in office is likely to depend on the performance of city manager, including it as a control variable might bias the results of estimation. For this reason I report the results both with and without the logarithm of tenure in office as a control variable.

Table 7 presents the results of the estimation of regression (3). The results indicate that an increase in the population achieved while city manager was in office in one city has a significant positive effect on the wage that city manager gets in the next city in which he/she works. The magnitude of the effect is quantitatively close to the effect of population growth on the wage in the same city estimated above - a 10 percent increase in population leads to about 2 percent increase in the wage of city manager. The size of tax revenues does not have a significant effect on the wage in the next city, although there is some evidence of positive effect of increasing tax revenue due to growth of population on city manager's wage in next city. Without controling for tenure the effect is slightly higher than the effect on wage in the same city, but becomes insignificant once we control for the length of tenure in office.

Thus, there is evidence that good performance of city manager is rewarded not only with higher wage in the same city, but also with higher wage in the city in which city manager works afterwards. The magnitude of the effect of performance on the wage in the current city and in the next city turns out to be very similar. This evidence is in line with the reward based explanation, since in this case the wage reflects city manager's ability to run local government. 


\subsection{Salary of Mayors}

To see whether the wage of all city officials automatically responds to city growth or it reflects the contribution of a particular officials to city growth, I examine performance elasticity of pay for mayor in cities with council-manager form of government. In these cities mayor usually serves as a member and presiding officer of the city council and does not have executive power. Thus, mayor in cities with council-manager form of government has a very limited effect on city growth and according to reward for performace explanation, measures of city growth should not affect salary of mayor.

Table 8 reports the results of the regressions with the same specification as in (1), but using the wage of mayor instead of the wage of city manager as a dependent variable. Controlling for city fixed effects all the coefficients are noticeable smaller than the corresponding estimates for city managers and are not statistical significant. Including city manager-city fixed effects reduces the magnitude of the coefficients even further, making them an order of magnitude smaller than the corresponding results for city managers from Table 4.

Thus, there is no evidence that wages of city officials are automatically increased as the size of the city and its tax revenues increases, since for the officials that have limited effect on city development we do not observe any association between wages and measures of performance. This evidence is also in line with the reward based explanation of the performance elasticity of pay, but is inconsistent with the constant relative pay model. It can be reconciled with the rent extraction explanation as long as mayors are limited not only in their ability to influence city development, but in their ability to extract rents as well. 


\subsection{Effect of Direct Democracy}

Voter initiatives are viewed as a mechanism that facilitates the flow of information to the voters and limits rent extraction by the politicians (Frey, 1994; Matsusaka, 1992, 1995). The main assumption is that voter initiative improves accountability of local governments. Thus, we should expect that in cities with voter initiative elasticity of city managers' wage with respect to city growth that reflects reward for performance is higher. In contrast, the part that reflects rent extraction should be lower. Consistent with this prediction, DiTella and Fisman (2004) show that in states that allow voter initiative have higher tax elasticities and lower income elasticities of gubernatorial pay.

Results in Table 9 demonstrate that regardless of the measure of performance the effect of voters initiative on the performance elasticity of city managers' pay is small in magnitude and never statistically significant. The results can be interpreted in two ways. One interpretation is that voter initiative does not work as an effective mechanism for limiting rent extraction at the city level. This interpretation does not allow to distinguish among different explanations of performance elasticity of pay. Alternative interpretation is that wage setting policy is aligned with the preferences of the voters, so that increasing voters say does not affect pay elasticity of city managers. This interpretation is consistent with both reward for performance and relative pay models, but can not be reconciled with rent extraction explanation.

\section{Conclusions}

Despite the important role that bureaucrats play in determining and implementing public policies, empirical research on the incentives of bureaucrats remains extremely limited. The paper is the first attempt to study monetary incentives that senior bureaucrats face. In 
particular, I use information on salaries of city managers in the U.S. municipalities between 1992 and 2003 to study performance elasticity of bureaucratic pay. Results challenge the standard assumption that bureaucrats always face low powered incentives. Salary of city managers is tightly linked to such measures of city growth as population and taxrevenues. The estimates suggest that the wage of city manager goes up by about 2 percent for every 10 percent increase in population or for every 10 percent increase in tax revenue caused by an increase in population.

Most importantly, the link between city managers' salary and growth of the city reflects reward for performance, rather than rent extraction, constant relative income or compensating differential approach to wage setting. In particular, wages of the city managers do not respond to exogenous shocks to city growth. Thus, at least for some senior buraucrats, the monetary rewards are more closely linked to their performance than for CEOs in private firms, who do get compensated for luck (Bertrand and Mullainathan, 2001)

Competition between local governments seems to be the main reason that explains why city managers face high powered incentive schemes. For most public officials monopoly position of government agencies in which they work and lack of proper comparison make career concerns and monitoring the main sources of incentives (Tirole, 1994). Local governments do not enjoy such a monopoly position and have to constantly compete with each other, since citizens can always vote with their feet to show their dissatisfaction with local government. Such competition provides proper comparison and better measures of performance of city managers. In addition, high mobility of city managers between different municipalities forces city councils to increase wage of city managers who have showed their ability to run local government to prevent them from moving to a different city. Thus, introducing competition between different government agencies can not only limit rent extraction (Shleifer and Vishny, 1993), but provide public officials with monetary rewards for 
performance.

\section{References}

1. Alesina, Alberto and Guido Tabellini (2007) "Bureaucrats or Politicians? Part I: A Single Policy Task." American Economic Review 97(1), 169-79

2. Alesina, Alberto and Guido Tabellini (2008) "Bureaucrats or Politicians? Part II: Multiple policy tasks." Journal of Public Economics, 92(3-4), 426-447.

3. Bertrand, Marianne and Sendhil Mullainathan (2001) "Are CEOs Rewarded for Luck? The Ones Without Prinicpals Are." Quarterly Journal of Economics 116, 901-932.

4. Besley, Timothy and Stephen Coate (2003) "Elected versus Appointed Regulators: Theory and Evidence." Journal of the European Economic Association 1(5), 11761206.

5. Carpenter, Daniel P. (2001) The Forging of Bureaucratic Autonomy: Reputations, Networks, and Policy Innovation in Executive Agencies1862-1928. Princeton, NJ: Princeton University Press.

6. Coate, Stephen and Brian Knight (2010) "Government Form and Public Spending: Theory and Evidence from U.S. Municipalities." Working paper.

7. Diermeier, Daniel, Michael Keane and Antonio Merlo (2005) "A Political Economy Model of Congressional Careers." American Economic Review, 95(1), 347-73.

8. Di Tella, Rafael and Raymond Fisman (2004) "Are Politicians Really Paid Like Bureaucrats?" Journal of Law and Economics, 47, 477-513. 
9. Enikolopov, Ruben (2010) "Politicians, Bureaucrats and Targeted Redistribution: The Role of Career Concerns." Working paper.

10. Hall, Brian J., and Liebman, Jeffrey B. (1998) "Are CEOs Really Paid like Bureaucrats?" Quarterly Journal of Economics, 113, 653-691.

11. Maskin, Eric and Jean Tirole (2004) "The Politician and the Judge: Accountability in Government." American Economic Review, 94(4), 1034-54.

12. Murphy, Kevin (1999) "Executive Compensation." Pages 3:2485-63 in Handbook of Labor Economics, edited by Orley Ashenfelter and David Card. Amsterdam:North Holland.

13. Peltzman, Sam (1992) "Voters as Fiscal Conservatives." Quarterly Journal of Economics, 107, 327-361.

14. Shleifer, Andrei and Robert Vishny (1993) "Corruption." Quarterly Journal of Economics, 108, 559-617.

15. Tiebout, Charles (1956) "A Pure Theory of Local Public Expenditures." Journal of Political Economy, 64, 416-424.

16. Tirole, Jean (1994) "The Internal Organization of Government." Oxford Economic Papers, 46, 1-29.

17. Wilson, James Q. (1989) Bureaucracy. New York: Basic Books.

18. Wolfers, Justin (2007) "Are Voters Rational? Evidence from Gubernatorial Elections." Working paper. 
Table 1. Individual Characteristics of City Managers.

\begin{tabular}{lcccc}
\hline \hline & Observations & Mean & Median & Std.Dev. \\
Graduate degree (\%) & 631 & 0.85 & 1 & 0.36 \\
Graduate degree in public administration (\%) & 631 & 0.60 & 1 & 0.49 \\
Female (\%) & 651 & 0.05 & 0 & 0.21 \\
Black (\%) & 474 & 0.02 & 0 & 0.13 \\
Hispanic (\%) & 475 & 0.02 & 0 & 0.14 \\
Tenure in office (including current position) & 1308 & 42.64 & 43 & 8.53 \\
Age at the Start of Current Work & 1411 & 5.48 & 5 & 3.41 \\
\hline \hline
\end{tabular}


Table 2. Descriptive Statistics.

\begin{tabular}{|c|c|c|c|c|c|c|c|c|c|}
\hline & \multicolumn{3}{|c|}{ Moving city managers subsample } & \multicolumn{3}{|c|}{ Salary information sample } & \multicolumn{3}{|c|}{ Whole sample of municipalities } \\
\hline & (1) & $(2)$ & (3) & (4) & $(5)$ & $(6)$ & (7) & $(8)$ & $(9)$ \\
\hline & Obs. & Mean & Std. Dev. & Obs. & Mean & Std. Dev. & Obs. & Mean & Std. Dev. \\
\hline Population & 13408 & 25666 & 51413 & 101512 & 22903 & 86530 & 17197 & 23611 & 48713 \\
\hline Income Per Capita & 1803 & 18830 & 11022 & 14248 & 18199 & 10435 & 71762 & 15244 & 7996 \\
\hline Urban population $(\%)$ & 1803 & 0.89 & 0.29 & 14246 & 0.85 & 0.33 & 71667 & 0.26 & 0.42 \\
\hline Population over $65(\%)$ & 1803 & 0.14 & 0.07 & 14246 & 0.15 & 0.06 & 71667 & 0.16 & 0.08 \\
\hline Inequality & 1803 & 1.26 & 0.15 & 14246 & 1.26 & 0.16 & 71667 & 1.22 & 0.25 \\
\hline Population with high school degree $(\%)$ & 1803 & 0.73 & 0.13 & 14246 & 0.72 & 0.13 & 71661 & 0.72 & 0.14 \\
\hline Unemployment $(\%)$ & 1803 & 0.06 & 0.03 & 14246 & 0.06 & 0.04 & 71581 & 0.06 & 0.05 \\
\hline Ethnolinguistic Fractionalization & 1803 & 0.26 & 0.19 & 14246 & 0.23 & 0.19 & 71667 & 0.12 & 0.15 \\
\hline Tax Revenue & 7487 & 15513 & 33814 & 54505 & 19035 & 90775 & 151424 & 12583 & 197265 \\
\hline Expenditure & 7487 & 42973 & 89673 & 54505 & 54363 & 261642 & 151424 & 35164 & 507314 \\
\hline Full time employees & 5512 & 356 & 747 & 39951 & 460 & 1961 & 133313 & 183 & 3721 \\
\hline Number of municipalities & & 932 & & & 7349 & & & 39161 & \\
\hline
\end{tabular}

Notes: The first subsample includes only municipalities in which at least one city manager was observed in another municipality. The second subsample includes all

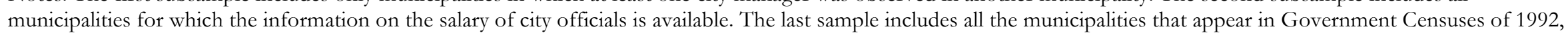
1997 or 2002. 
Table 3. City managers' Wages.

\begin{tabular}{|c|c|c|c|c|c|c|}
\hline \multicolumn{7}{|c|}{ Panel A. Average Wages in 1992-2003 (in 2000 dollars) } \\
\hline \multirow[b]{2}{*}{ Year } & \multicolumn{3}{|c|}{ Moving city managers sample } & \multicolumn{3}{|c|}{ Salary information sample } \\
\hline & Mean & Median & Obs. & Mean & Median & Obs. \\
\hline 1992 & 75338 & 70311 & 630 & 73104 & 68495 & 2382 \\
\hline 1993 & 75526 & 71523 & 625 & 72882 & 68387 & 2406 \\
\hline 1995 & 75117 & 72301 & 604 & 73745 & 70608 & 2370 \\
\hline 1996 & 77432 & 73970 & 620 & 75055 & 71662 & 2429 \\
\hline 1997 & 76928 & 73888 & 636 & 75520 & 72172 & 2436 \\
\hline 1998 & 79413 & 75446 & 650 & 77066 & 73942 & 2486 \\
\hline 1999 & 80039 & 75667 & 648 & 78095 & 74424 & 2366 \\
\hline 2000 & 80730 & 75142 & 622 & 78890 & 74984 & 2319 \\
\hline 2001 & 84400 & 80059 & 480 & 82969 & 79153 & 1754 \\
\hline 2002 & 84917 & 80414 & 501 & 84811 & 80854 & 1782 \\
\hline 2003 & 87886 & 82443 & 566 & 86500 & 81667 & 2087 \\
\hline \multicolumn{7}{|c|}{ Panel B. Changes in Wages of Individual City Mangers (in nominal dollars) } \\
\hline & Observations & Mean & Median & Std.Dev. & $\begin{array}{c}\text { Share of } \\
\text { Zeros }\end{array}$ & $\begin{array}{c}\text { Share of } \\
\text { Negative } \\
\text { Values }\end{array}$ \\
\hline $\begin{array}{l}\text { Yearly Change in } \\
\text { Wage, Same City }\end{array}$ & 2190 & 3280 & 2746 & 6168 & $10.6 \%$ & $9.7 \%$ \\
\hline $\begin{array}{l}\text { Change in Wage, } \\
\text { Move to New } \\
\text { City }\end{array}$ & 353 & 11291 & 9500 & 18828 & $0.6 \%$ & $21.0 \%$ \\
\hline
\end{tabular}

Notes:. In Panel A the first subsample includes only municipalities in which at least one city manager was observed in another municipality. The second subsample includes all municipalities for which the information on the salary of city officials is available. 
Figure 1. Median Wages of City Managers and Local Public Employees

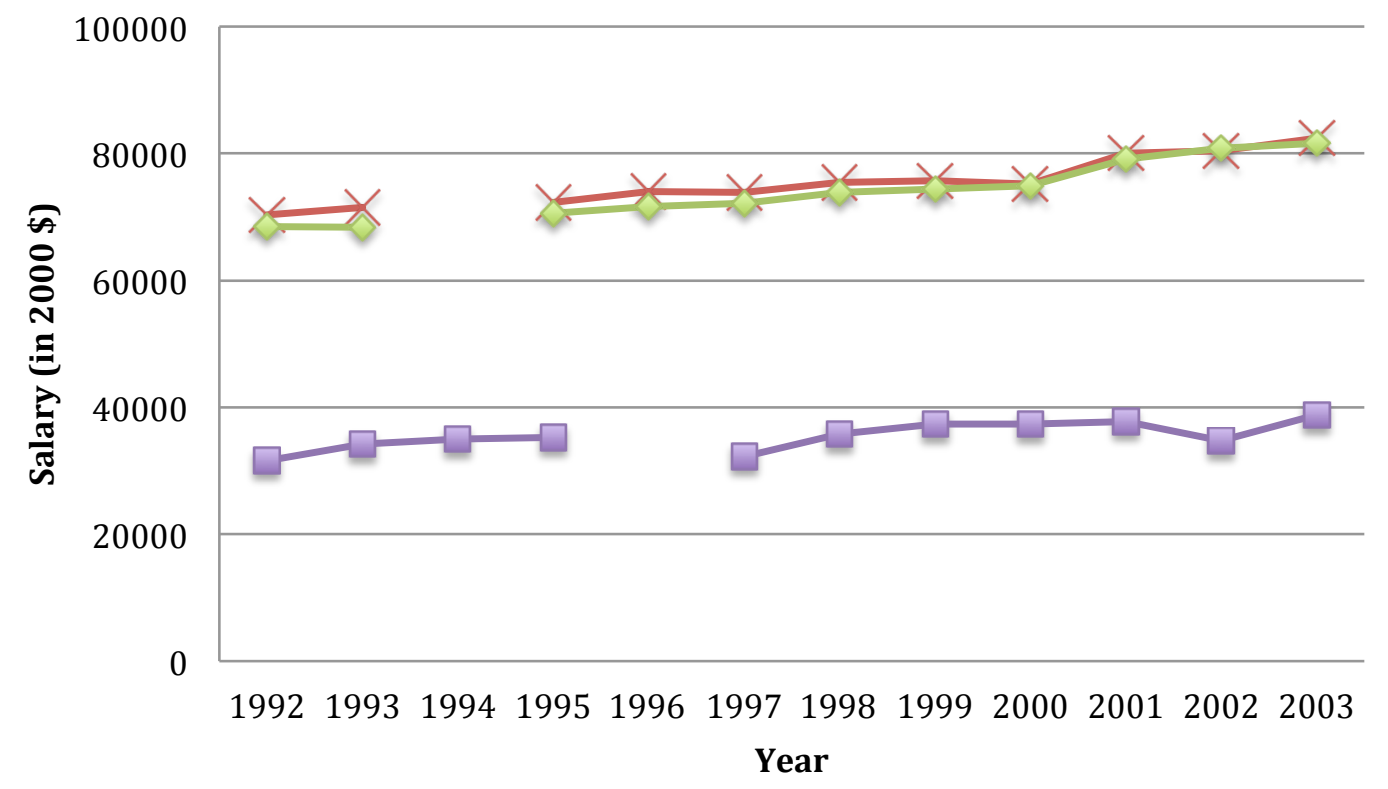

$\leftarrow$ City Managers in Sample $\sim$ All City Managers $\square-$ Local Public Employees 
Table 4. Effect of City Development on City Manager's Wage.

\begin{tabular}{|c|c|c|c|c|c|c|c|c|}
\hline & & & & age of City & Manager) & & & \\
\hline & (1) & (2) & (3) & (4) & (5) & (6) & (7) & (8) \\
\hline & OLS & OLS & OLS & OLS & OLS & OLS & IV & IV \\
\hline $\ln$ (Population) & 0.1628 & 0.1864 & & & 0.1766 & 0.2125 & & \\
\hline & {$[0.051]^{* * *}$} & {$[0.055]^{* * *}$} & & & {$[0.064]^{* * *}$} & {$[0.069]^{* * *}$} & & \\
\hline $\ln ($ Tax Revenue $)$ & & & 0.0405 & 0.0365 & 0.0212 & 0.0171 & 0.1863 & 0.2887 \\
\hline & & & {$[0.015]^{* * *}$} & {$[0.016]^{* *}$} & {$[0.013]$} & {$[0.013]$} & {$[0.073]^{* *}$} & {$[0.112]^{* *}$} \\
\hline $\ln ($ Tenure) & 0.02 & & 0.0217 & & 0.0208 & & 0.0253 & \\
\hline & {$[0.007]^{* * *}$} & & {$[0.007]^{* * *}$} & & {$[0.007]^{* * *}$} & & {$[0.009]^{* * *}$} & \\
\hline Age & 0.0203 & & 0.0173 & & 0.0165 & & 0.0166 & \\
\hline & {$[0.006]^{* * *}$} & & {$[0.007]^{* *}$} & & {$[0.007]^{* *}$} & & {$[0.009]^{*}$} & \\
\hline Age squared & -0.0002 & & -0.0002 & & -0.0001 & & -0.0002 & \\
\hline & {$[0.000]^{* * *}$} & & {$[0.000]^{* *}$} & & {$[0.000]^{*}$} & & {$[0.000]$} & \\
\hline Female & -0.0506 & & -0.0581 & & -0.0608 & & -0.0658 & \\
\hline & {$[0.025]^{* *}$} & & {$[0.027]^{* *}$} & & {$[0.029]^{* *}$} & & {$[0.033]^{* *}$} & \\
\hline Black & -0.0328 & & -0.026 & & -0.026 & & -0.0207 & \\
\hline & {$[0.051]$} & & {$[0.051]$} & & {$[0.051]$} & & {$[0.062]$} & \\
\hline City fixed effect & Yes & No & Yes & No & Yes & No & Yes & No \\
\hline City manager-city fixed effects & No & Yes & No & Yes & No & Yes & No & Yes \\
\hline Year fixed effects & Yes & Yes & Yes & Yes & Yes & Yes & Yes & Yes \\
\hline Observations & 2,227 & 2,819 & 2,017 & 2,563 & 1,822 & 2,304 & 1,822 & 2,304 \\
\hline Number of cities & 607 & 946 & 634 & 969 & 576 & 883 & 576 & 883 \\
\hline R-squared & 0.86 & 0.82 & 0.88 & 0.81 & 0.87 & 0.82 & 0.98 & 0.98 \\
\hline
\end{tabular}

Notes: The sample includes only observations for city managers that are observed in more than one municipality. Standard errors clustered at the city level in parenthesis. In specification (4) logarithm of tax revenues is instrumented with logarithm of population. In specifications (7)-(8) logarithm of tax revenues is instrumented with logarithm of population.

* significant at $10 \%$; ** significant at $5 \%$; *** significant at $1 \%$. 
Table 5. Effect of City Development on City Manager's Wage (whole sample).

\begin{tabular}{|c|c|c|c|c|}
\hline & \multicolumn{4}{|c|}{ ln(Wage of City Manager) } \\
\hline & (1) & (2) & (3) & (4) \\
\hline & OLS & OLS & OLS & IV \\
\hline \multirow[t]{2}{*}{$\ln$ (Population) } & 0.201 & & 0.187 & \\
\hline & {$[0.016]^{* * *}$} & & {$[0.019]^{* * *}$} & \\
\hline \multirow[t]{2}{*}{$\ln ($ Tax Revenue $)$} & & 0.030 & 0.012 & 0.223 \\
\hline & & {$[0.008]^{* * *}$} & {$[0.007]^{*}$} & {$[0.025]^{* * *}$} \\
\hline City fixed effects & Yes & Yes & Yes & Yes \\
\hline Year fixed effects & Yes & Yes & Yes & Yes \\
\hline Observations & 22050 & 19751 & 17721 & 17721 \\
\hline Number of cities & 3258 & 3614 & 3215 & 3215 \\
\hline R-squared & 0.95 & 0.96 & 0.96 & 0.95 \\
\hline
\end{tabular}

Notes: The sample includes all observations for which the information on city managers' salary is available. Standard error clustered at the city level in parenthesis. In specification (4) logarithm of tax revenues is instrumented with logarithm of population.

* significant at $10 \%$;* significant at $5 \%$; ** significant at $1 \%$. 
Table 6. Effect of Observable Shocks in Measures of City Development on City Manager's Wage.

\begin{tabular}{|c|c|c|c|c|}
\hline & \multicolumn{4}{|c|}{$\ln ($ Wage of City Manager) } \\
\hline & (1) & (2) & (3) & (4) \\
\hline & IV & IV & IV & IV \\
\hline \multirow[t]{2}{*}{$\ln$ (Population) } & -0.180 & 0.270 & & \\
\hline & {$[0.340]$} & {$[0.372]$} & & \\
\hline \multirow[t]{2}{*}{$\ln ($ Tax Revenue $)$} & & & -0.143 & 0.279 \\
\hline & & & {$[0.323]$} & {$[0.304]$} \\
\hline \multirow[t]{2}{*}{$\ln$ (Tenure) } & 0.023 & & 0.019 & \\
\hline & {$[0.007]^{* * *}$} & & {$[0.011]^{*}$} & \\
\hline \multirow[t]{2}{*}{ Age } & 0.023 & & 0.020 & \\
\hline & {$[0.007]^{* * *}$} & & {$[0.009]^{* *}$} & \\
\hline \multirow[t]{2}{*}{ Age squared } & 0.000 & & 0.000 & \\
\hline & {$[0.000]^{* * *}$} & & {$[0.000]^{*}$} & \\
\hline \multirow[t]{2}{*}{ Female } & -0.065 & & -0.069 & \\
\hline & {$[0.029]^{* *}$} & & {$[0.034]^{* *}$} & \\
\hline \multirow[t]{2}{*}{ Black } & -0.027 & & -0.025 & \\
\hline & {$[0.051]$} & & {$[0.051]$} & \\
\hline City fixed effect & Yes & No & Yes & No \\
\hline City manager-city fixed effects & No & Yes & No & Yes \\
\hline Year fixed effects & Yes & Yes & Yes & Yes \\
\hline Observations & 2,107 & 2,571 & 1,674 & 2,021 \\
\hline Number of cities & 491 & 616 & 432 & 539 \\
\hline $\begin{array}{l}\text { F-test for exclusion of instruments } \\
\text { (clustered standard errors) }\end{array}$ & 8.54 & 9.341 & 1.433 & 2.822 \\
\hline $\begin{array}{l}\text { F-test for exclusion of instruments } \\
\text { (standard errors not clustered) }\end{array}$ & 22.13 & 24.23 & 2.698 & 6.067 \\
\hline
\end{tabular}


Table 7. Effect of City Development on City Manager's Wage in the Next City.

\begin{tabular}{|c|c|c|c|c|c|c|c|c|}
\hline & \multicolumn{8}{|c|}{$\ln ($ Wage in Next City) } \\
\hline & (1) & $(2)$ & (3) & (4) & (5) & (6) & (7) & (8) \\
\hline & OLS & OLS & OLS & OLS & OLS & OLS & IV & IV \\
\hline \multirow[t]{2}{*}{ In (Population) } & 0.2454 & 0.1741 & & & 0.2304 & 0.2039 & & \\
\hline & {$[0.091]^{* * *}$} & {$[0.087]^{* *}$} & & & {$[0.129]^{*}$} & {$[0.121]^{*}$} & & \\
\hline \multirow[t]{2}{*}{$\ln ($ Tax Revenue) } & & & 0.0585 & 0.0115 & 0.0245 & -0.0183 & 0.2412 & 0.1988 \\
\hline & & & {$[0.038]$} & {$[0.038]$} & {$[0.045]$} & {$[0.046]$} & {$[0.113]^{* *}$} & {$[0.124]$} \\
\hline \multirow[t]{2}{*}{ Initial $\ln ($ Population $)$} & -0.0861 & -0.0164 & & & -0.1661 & -0.1392 & 0.0423 & 0.0441 \\
\hline & {$[0.091]$} & {$[0.086]$} & & & {$[0.129]$} & {$[0.121]$} & {$[0.023]^{*}$} & {$[0.022]^{* *}$} \\
\hline \multirow[t]{2}{*}{ Initial $\ln ($ Tax Revenue $)$} & & & 0.075 & 0.12 & 0.0703 & 0.1108 & -0.1247 & -0.0853 \\
\hline & & & {$[0.036]^{* *}$} & {$[0.036]^{* * *}$} & {$[0.044]$} & {$[0.044]^{* *}$} & {$[0.106]$} & {$[0.117]$} \\
\hline \multirow[t]{2}{*}{ Age } & 0.0295 & 0.0258 & 0.0186 & 0.0165 & 0.0181 & 0.0159 & 0.0176 & 0.0163 \\
\hline & {$[0.013]^{* *}$} & {$[0.013]^{* *}$} & {$[0.016]$} & {$[0.016]$} & {$[0.016]$} & [0.016] & {$[0.015]$} & {$[0.015]$} \\
\hline \multirow[t]{2}{*}{ Age squared } & -0.0003 & -0.0003 & -0.0002 & -0.0002 & -0.0002 & -0.0002 & -0.0002 & -0.0002 \\
\hline & {$[0.000]^{* *}$} & {$[0.000]^{*}$} & {$[0.000]$} & {$[0.000]$} & {$[0.000]$} & {$[0.000]$} & {$[0.000]$} & {$[0.000]$} \\
\hline \multirow[t]{2}{*}{$\ln ($ Tenure $)$} & & 0.0549 & & 0.0604 & & 0.0595 & & 0.0373 \\
\hline & & {$[0.017]^{* * *}$} & & {$[0.018]^{* * *}$} & & {$[0.019]^{* * *}$} & & {$[0.025]$} \\
\hline Year fixed effects & Yes & Yes & Yes & Yes & Yes & Yes & Yes & Yes \\
\hline Observations & 570 & 570 & 496 & 496 & 445 & 445 & 445 & 445 \\
\hline R-squared & 0.49 & 0.50 & 0.53 & 0.54 & 0.55 & 0.56 & 0.53 & 0.54 \\
\hline
\end{tabular}

Notes: The sample includes only observations for city managers that are observed in more than one municipality. Standard errors clustered at the city level in parenthesis. In specification (4) logarithm of tax revenues is instrumented with logarithm of population. In specifications (7)-(8) logarithm of tax revenues is instrumented with logarithm of population.

$*$ significant at $10 \%$; ** significant at $5 \%$; *** significant at $1 \%$. 
Table 8. Effect of City Development on Wage of Mayors in cities with Council-Manager form of government.

\begin{tabular}{lcccccccc}
\hline \hline & & \multicolumn{7}{c}{$\ln$ (Wage of Mayor) } \\
& $(1)$ & $(2)$ & $(3)$ & $(4)$ & $(5)$ & $(6)$ & $(7)$ & $(8)$ \\
$\ln$ (Population) & OLS & OLS & OLS & OLS & OLS & OLS & IV & IV \\
\cline { 2 - 9 } & 0.068 & 0.027 & & & 0.120 & 0.033 & & \\
$\ln$ (Revenue) & {$[0.190]$} & {$[0.188]$} & & & {$[0.218]$} & {$[0.236]$} & & \\
& & & 0.040 & -0.017 & 0.023 & -0.034 & 0.176 & 0.016 \\
City fixed effect & & & {$[0.063]$} & {$[0.066]$} & {$[0.062]$} & {$[0.066$} & {$[0.344]$} & {$[0.474]$} \\
City manager-city fixed & Yes & No & Yes & No & Yes & No & Yes & No \\
effects & No & Yes & No & Yes & No & Yes & No & Yes \\
Year fixed effects & Yes & Yes & Yes & Yes & Yes & Yes & Yes & Yes \\
\hline Observations & 2,015 & 2,015 & 1,811 & 1,811 & 1,657 & 1,657 & 1,657 & 1,657 \\
Number of cities & 632 & 730 & 646 & 734 & 592 & 672 & 592 & 672 \\
R-squared & 0.14 & 0.10 & 0.13 & 0.09 & 0.15 & 0.11 & 0.93 & 0.94 \\
\hline \hline
\end{tabular}

Notes: Standard errors clustered at the city level in parenthesis. In specifications (7) and (8) logarithm of tax revenues is instrumented with logarithm of population.

* significant at $10 \%$;** significant at $5 \%$; *** significant at $1 \%$. 
Table 9. Effect of Voter Initiative.

\begin{tabular}{|c|c|c|c|c|}
\hline & \multicolumn{4}{|c|}{$\ln ($ Wage of City Manager) } \\
\hline & $(1)$ & $(2)$ & (3) & (4) \\
\hline & OLS & OLS & OLS & IV \\
\hline \multirow[t]{2}{*}{$\ln$ (Population) } & 0.1937 & & 0.2093 & \\
\hline & {$[0.051]^{* * *}$} & & {$[0.060]^{* * *}$} & \\
\hline \multirow[t]{2}{*}{$\ln ($ Revenue $)$} & & 0.0486 & 0.0193 & 0.2769 \\
\hline & & {$[0.020]^{* *}$} & {$[0.017]$} & {$[0.105]^{* * *}$} \\
\hline \multirow[t]{2}{*}{$\ln ($ Population $) \times$ Voter Initiative in City } & -0.0117 & & -0.0187 & \\
\hline & {$[0.009]$} & & {$[0.018]$} & \\
\hline \multirow[t]{2}{*}{$\ln ($ Revenue $) \times$ Voter Initiative in City } & & -0.0111 & 0.0032 & -0.0155 \\
\hline & & {$[0.007]$} & {$[0.014]$} & {$[0.011]$} \\
\hline \multirow[t]{2}{*}{ Voter Initiative in City } & 0.0935 & 0.0861 & 0.1497 & 0.1259 \\
\hline & {$[0.081]$} & {$[0.059]$} & {$[0.089]^{*}$} & {$[0.091]$} \\
\hline Year fixed effects & Yes & Yes & Yes & Yes \\
\hline City fixed effects & Yes & Yes & Yes & Yes \\
\hline Observations & 2,420 & 2,178 & 1,985 & 1,985 \\
\hline Number of cities & 688 & 709 & 649 & 649 \\
\hline R-squared & 0.85 & 0.84 & 0.85 & 0.97 \\
\hline
\end{tabular}

Notes: Standard errors clustered at the city level in parenthesis. In specification (4) logarithm of budget revenues is instrumented with logarithm of population.

* significant at $10 \%$; ** significant at $5 \%$; *** significant at $1 \%$. 